\title{
Increased Endothelial Albumin Permeability Mediated by Protein Kinase C Activation
}

Joseph J. Lynch, Thomas J. Ferro, Frank A. Blumenstock, Anne M. Brockenauer, and Asrar B. Malik

Departments of Medicine, Biochemistry, and Physiology, The Albany Medical College of Union University, and The Veterans Administration Medical Center, Albany, New York 12208

\begin{abstract}
We examined the effects of activation of endothelial protein kinase C (PKC) of the endothelial barrier function. Exposure of confluent bovine pulmonary artery endothelial cell monolayers to phorbol 12-myristate 13-acetate (PMA) resulted in concentration-dependent $\left(10^{-8}-10^{-6} \mathrm{M}\right)$ increases in PKC activity and in the transendothelial flux of ${ }^{125} \mathrm{I}$-albumin. Exposure of the endothelium to 1-oleoyl 2-acetyl glycerol (OAG) also increased the transendothelial flux of ${ }^{125} \mathrm{I}$-albumin in a concentration-dependent manner. Neither $4 \alpha$-phorbol didecanoate nor 1-mono-oleoyl glycerol, which do not activate PKC, altered permeability. The increase in ${ }^{125} \mathrm{I}$-albumin permeability induced by PMA was inhibited by $25 \mu$ M H7 (a PKC inhibitor), but not by the control compound HA1004 (25 $\mu \mathrm{M})$. After $16 \mathrm{~h}$ of exposure to PMA, ${ }^{125} \mathrm{I}$-albumin permeability returned to baseline and a significant reduction in cytosolic PKC activity was noted. Further challenge with PMA at this time resulted in no significant increase in PKC activity indicating downregulation of the enzyme; moreover, this PMA challenge did not increase endothelial permeability. Exposure of endothelial monolayers to phospholipase C (PLC), which increases membrane phosphatidylinositide turnover, or to $\alpha$-thrombin also induced concentration-dependent activation of PKC and increases in ${ }^{125} \mathrm{I}$-albumin endothelial permeability. The thrombin- and PLC-induced permeability increases were inhibited by H7, but not by HA1004. The activation of endothelial PKC directly by PMA or OAG and by PLC and $\alpha$-thrombin increases the transendothelial albumin permeability, indicating that PKC activation is an important signal transduction pathway by which extracellular mediators increase endothelial macromolecular transport. (J. Clin. Invest. 1990. 85:19911998.) endothelial albumin transport • endothelial monolayer • protein kinase $\mathrm{C} \cdot$ second messengers $\bullet$ phospholipase $\mathrm{C} \cdot \alpha$ thrombin
\end{abstract}

\section{Introduction}

Increased pulmonary vascular permeability is a characteristic feature of inflammatory lung injury (1), including the adult respiratory distress syndrome (2). Increases in vascular permeability are noted in response to a variety of inflammation-provoking stimuli: $\alpha$-thrombin (3), endotoxin (4), disseminated

Address reprint requests to Dr. Malik, The Albany Medical College (A-66), Albany, NY 12208.

Received for publication 16 December 1988 and in revised form 28 November 1989.

J. Clin. Invest.

(c) The American Society for Clinical Investigation, Inc. 0021-9738/90/06/1991/08 $\$ 2.00$

Volume 85, June 1990, 1991-1998 intravascular coagulation (5), fat embolism (6), and oxygen radicals (7). Morphological and functional studies of endothelial cells show characteristic similarities in the response to various inflammatory mediators $(8,9) ;(a)$ increase in endothelial permeability to macromolecules $(3,10),(b)$ a change in the shape of endothelial cells (i.e., a "rounding up" of endothelial cells) (11), and (c) activation of second messenger systems secondary to the breakdown of membrane phospholipids and generation of inositol phosphates and 1,2-diacylglycerol (12).

The relationship between the activation of these second messenger pathways and the increase in endothelial permeability remains unclear. The activation of protein kinase $\mathrm{C}$ (PKC), ${ }^{1}$ which can occur as a result of the generation of $1,2-$ diacylglycerol (13), decreases transepithelial resistance (14), suggesting that second messengers regulate the epithelial barrier transport via a PKC-dependent pathway. The loss of epithelial barrier function secondary to PKC activation is associated with the phosphorylation of specific cytoskeletal proteins $(15)$ and decreased cell-cell contacts $(15,16)$. Endothelial cell barrier function, which is also the result of cell-cell interactions, may be modified by second messenger pathways (17) via the activation of PKC. In this study, we postulated that activation of PKC mediates the altered endothelial barrier function seen in response to extracellular mediators.

We present evidence that the activation of endothelial PKC using either phorbol 12-myristate 13-acetate (a phorbol ester) or 1-oleoyl 2-acetyl glycerol (a 1,2-diacylglycerol analogue) resulted in PKC activation and increase in the transendothelial flux of ${ }^{125} \mathrm{I}$-albumin, which is not due to cytolysis. The exposure of endothelial monolayers to phospholipase $\mathrm{C}$, a membrane phosphodiesterase, which hydrolyzes phosphatidylinositides to 1,2-diacylglycerol (18), also increased PKC activity and transendothelial ${ }^{125} \mathrm{I}$-albumin permeability in a concentration-dependent manner. Moreover, the permeabilityincreasing effect of $\alpha$-thrombin (3), an extracellular mediator, is mediated in part by the activation of endothelial PKC. The results of this study indicate that the activation of endothelial PKC, subsequent to increased phosphatidylinositol turnover, is a common pathway by which mediators increase transendothelial permeability during tissue inflammation.

\section{Methods}

Preparation of endothelial monolayers. Bovine pulmonary artery endothelial cells were removed from the main pulmonary artery after incubation with $0.65 \%$ collagenase, seeded on $60-\mathrm{mm}$ petri dishes, and grown to confluence. The cells were identified as being endothelial, without contaminating fibroblasts or smooth muscle cells, using phase contrast microscopy, presence of Factor VIII-related antigen as dem-

1. Abbreviations used in this paper: $\mathrm{LDH}$, lactate dehydrogenase; $\mathrm{ME}$, mercaptoethanol; MOG, 1-mono-oleoyl glycerol; OAG, 1-oleoyl 2acetyl glycerol; PKC, protein kinase C; PLC, phospholipase C. 
onstrated by indirect immunofluorescence, uptake of acylated low density lipoproteins, presence of angiotensin-converting enzyme, and electron microscopic appearance (19). At five to seven population doublings, the endothelial monolayer was removed using $0.025 \%$ trypsin and centrifuged $(100 \mathrm{~g} ; 5 \mathrm{~min})$. The cells $\left(8 \times 10^{5} \mathrm{cells} / \mathrm{ml}\right)$ were resuspended in Dulbecco's modified Eagle medium (DME) and seeded as described below.

${ }^{125}$ I-albumin endothelial permeability assay. Polycarbonate micropore membranes (13-mm diam; 0.8- $\mu \mathrm{m}$ pore size; Nuclepore Corp., Pleasanton, CA) were gelatinized (type II calf skin gelatin; Sigma Chemical Co., St. Louis, MO) as previously described (3), mounted on plastic cylinders ( $9 \mathrm{~mm}$ i.d.; Adaps, Dedham, MA), and sterilized by ultraviolet light for $24 \mathrm{~h}$. Endothelial cells $\left(2 \times 10^{5}\right.$ in $0.25 \mathrm{ml}$ of DME) were then seeded to the gelatinized membranes and cultured for $4 \mathrm{~d}$ $\left(37^{\circ} \mathrm{C} ; 5 \% \mathrm{CO}_{2}\right)$ to allow the cells to develop confluency. The confluent monolayer demonstrated the typical cobblestone appearance.

The experimental apparatus for the study of transendothelial transport in the absence of hydrostatic and oncotic pressure gradients has been described (3). In brief, the system consists of two compartments that communicate solely by a microporous polycarbonate membrane lined with the endothelial cell monolayer as described above. The luminal (upper) compartment ( $0.7 \mathrm{ml}$ capacitý) was suspended in the abluminal (lower) compartment ( $25 \mathrm{ml}$ capacity). The lower compartment was stirred continuously for complete mixing. The entire system was kept in a water bath at a constant temperature of $37^{\circ} \mathrm{C}$. The fluid height in both compartments was the same to eliminate convective flux.

Hanks' balanced salt solution (HBSS) containing $0.5 \%$ bovine serum albumin (Sigma Chemical Co.) and $20 \mathrm{mM}$ Hepes buffer was used on both sides of the monolayer. Albumin labeled with ${ }^{125} \mathrm{I}$ (New England Nuclear, Boston, MA) using the chloramine- $t$ method (20) was added to the upper compartment. ${ }^{125} \mathrm{I}$-albumin was extensively dialyzed against $\mathrm{KI}$ before use; the free ${ }^{125} \mathrm{I}$ was always less than $1 \%$. A maximum of $1.0 \mathrm{mCi}$ in $0.7 \mathrm{ml}$ of HBSS was added per well. Two $25-\mu \mathrm{l}$ samples were taken at the beginning of each study to determine the initial radioactivity of the upper compartment. Samples were taken from the lower compartment every $5 \mathrm{~min}$ for $\mathbf{3 0} \mathrm{min}$ before the interventions, and then for $30 \mathrm{~min}$ after the interventions. The interventions were added to the upper compartment mixed in $50 \mu$ l of HBSS The radioactivity of the samples was measured in a gamma counter (United Technologies Packard, Sterling, VA). The clearance rates of ${ }_{125}$ I-albumin was determined by least squares linear regression for the control and experimental groups (21).

Assay of protein kinase $C$ activity. The technique was modified from the methods of Wolfson et al. (22) and Sahal et al. (23). Bovine pulmonary artery endothelial cells were seeded in tissue culture roller bottles (Corning Plasticware, Corning, NY). The cells were incubated in conditions identical to those for endothelial cells seeded to polycarbonate filters for the permeability assay. The roller bottles contained confluent endothelial cells $\left(\sim 1.2 \times 10^{9}\right.$ cells per bottle; one experimental condition per bottle) in DME with $10 \%$ FCS. Interventions were added to the roller bottles in $100 \mathrm{ml} \mathrm{HBSS}, 37^{\circ} \mathrm{C}$, pH 7.5 for 5 $\mathrm{min}$. The roller bottles were then promptly washed twice with ice-cold PBS (Gibco Laboratories, Grand Island, NY) containing $10 \mathrm{mM}$ EDTA. Extraction buffer A (150 mM Tris- $\mathrm{HCl}$ pH of $7.5 ; 150 \mathrm{mM}$ 2-mercaptoethanol [ME]; $3 \mathrm{mM}$ PMSF, and $6 \mathrm{mM}$ EGTA) was added $(2 \mathrm{ml})$ to the roller bottles, in which the cells were removed by manual scraping with a rubber policeman and disrupted mechanically in a loose-fitting glass-glass Dounce homogenizer. Subsequent procedures were performed at $4^{\circ} \mathrm{C}$. The homogenate was centrifuged at $10,000 \mathrm{~g}$ for $1 \mathrm{~h}$. The supernatant (the cytosolic fraction) was saved and the pellet was resuspended to the original volume in extraction buffer containing $50 \mathrm{mM}$ Tris- $\mathrm{HCl}$, pH 7.5; $50 \mathrm{mM}$ 2-ME; $1 \mathrm{mM}$ PMSF, and 2 mM EGTA with $0.1 \%$ Triton $X-100$. These samples were again subjected to homogenization and ultracentrifugation for $1 \mathrm{~h}$. This supernatant (containing the soluble membrane fraction) was also saved and the pellet was discarded. Preliminary studies confirmed that minimal phospholipid-dependent activity existed in the insoluble membrane extracts. Cytosolic and soluble membrane extracts were subjected to DEAE-cellulose ion exchange chromatography as described previously (24). All fractions were stored at $-70^{\circ} \mathrm{C}$ and assayed within $24 \mathrm{~h}$.

The standard assay mixture $(100 \mu \mathrm{l})$ contained assay buffer $(35 \mathrm{mM}$ Tris- $\mathrm{HCl}, \mathrm{pH}$ 7.5; $2 \mathrm{mM}$ 2-ME; $1.0 \mathrm{mM}$ PMSF; 0.01\% Triton X-100; $0.4 \mathrm{mM}$ EGTA; $0.4 \mathrm{mM}$ EDTA: $5 \mathrm{mM} \mathrm{MgCl}$; $1.5 \mathrm{mM} \mathrm{CaCl}_{2}$ ); $50 \mu \mathrm{M}$ ATP; ${ }^{32} \mathrm{P}$-ATP (200-500 cpm/pmol); and histone $\mathrm{H} 1$ (25 $\mu \mathrm{g} /$ assay); with or without activators (10 $\mu \mathrm{g}$ phosphatidylserine and $25 \mu \mathrm{g} \mathrm{1,2-}$ diolein). Phosphatidylserine, 1,2-diolein, 2-ME, and PMSF were prepared freshly on the day of assay. The amount of cell fraction to be added was determined before assay using the equivalent activity of 10 $\mu \mathrm{g}$ of cell protein before DEAE-cellulose chromatography by the Lowry method (25), which was nearly constant at $10 \mu \mathrm{g} / 10 \mu \mathrm{l}$ per assay. Incubations were carried out at $37^{\circ} \mathrm{C}$ for $5 \mathrm{~min}$. The reaction was stopped by the addition of a 1,000-fold excess of unlabeled ice-cold ATP and the entire assay mixture was pipetted onto a $2 \times 2 \mathrm{~cm}$ square of phosphocellulose filter paper P-81; Whatman, Inc., Englewood Cliffs, NJ). The filters were then washed thrice with $10 \%$ TCA with 20 mM Na-pyrophosphate, once with isopropanol, and allowed to air dry. Individual filters were quantified by counting in a Tricarb $2000 \mathrm{CA}$ Liquid Scintillation Analyzer (United Technologies Packard). Assays were made in triplicate and in the presence and absence of the activators (phosphatidylserine and 1,2-diolein). Activity was expressed as "units" of kinase activity (picomoles of ${ }^{32} \mathrm{P}$ incorporated per minute per milligram of protein fraction added per milligram histone used [pmol/mg/mg/min]). Net PKC activity was the value obtained by subtracting the kinase activity measured in the absence of activators from the activity measured in the presence of activators. Although absolute quantities of kinase recovery varied among cell batches, controls were performed for each group of interventions and these were consistent within each batch.

Interventions. Interventions used in the permeability and PKC assays were: (a) PMA, (b) $4 \alpha$-phorbol 12,13-didecanoate (4 $\alpha$-PDD), (c) 1-oleoyl 2-acetyl glycerol (OAG), (d) 1-mono-oleoyl glycerol (MOG), $(e)$ phospholipase $\mathrm{C},(f)$ purified human $\alpha$-thrombin (prepared by $\mathrm{Dr}$. John Fenton, the New York State Department of Health and the Albany Medical College, Albany, NY, as described by him [26]), and (g) dimethyl sulfoxide (DMSO) as control. These reagents (except $\alpha$ thrombin) were obtained from Sigma Chemical Co. The lipids (OAG and MOG) were ultrasonically dispersed into HBSS immediately before addition to the endothelial mbnolayer. The effects of varying concentrations of the interventions indicated above were studied.

Inhibition of PKC. Bovine pulmonary artery endothelial monolayers were preincubated $\left(30 \mathrm{~min} ; 37^{\circ} \mathrm{C} ; 5 \% \mathrm{CO}_{2} ; \mathrm{pH}\right.$ of 7.4$)$ with DME containing either the isoquinolinylsulfonamide derivative $\mathrm{H} 7$ (an inhibitor of PKC [27]) or HA1004 (as the control agent [27]). H7 and HA1004 were obtained from Seikagaku America Inc., St. Petersburg, FL.

Time course of phorbol ester effect on endothelial permeability. To study the effects of PKC downregulation on endothelial permeability responses, PMA (final concentration $10^{-7} \mathrm{M}$ ) in DMSO in HBSS or the vehicle DMSO in HBSS was pipetted gently into the culture medium. At the end of the 8- or 16-h incubation period, both the PMAchallenged and control groups were treated with either PMA $\left(10^{-7} \mathrm{M}\right)$ or vehicle for $5 \mathrm{~min}$, and ${ }^{125} \mathrm{I}$-albumin permeability was assayed as described above.

To assess whether PMA treatment resulted in PKC downregulation, PMA (final concentration $10^{-7} \mathrm{M}$ ) in DMSO in HBSS was pipetted into the roller bottles containing the pulmonary artery endothelial cell monolayers. At the end of the 16-h incubation period, the PMAchallenged groups were treated with either PMA $\left(10^{-7} \mathrm{M}\right)$ or with the vehicle for $5 \mathrm{~min}$ as above. The cytosolic and membrane-bound PKC activities were assessed as described previously.

Assay of lactate dehydrogenase ( $L D H)$ release. LDH release from bovine pulmonary artery endothelial monolayers was determined (28). The bovine pulmonary artery endothelial monolayers were prepared as above, except that the cells were seeded onto plastic tissue culture 

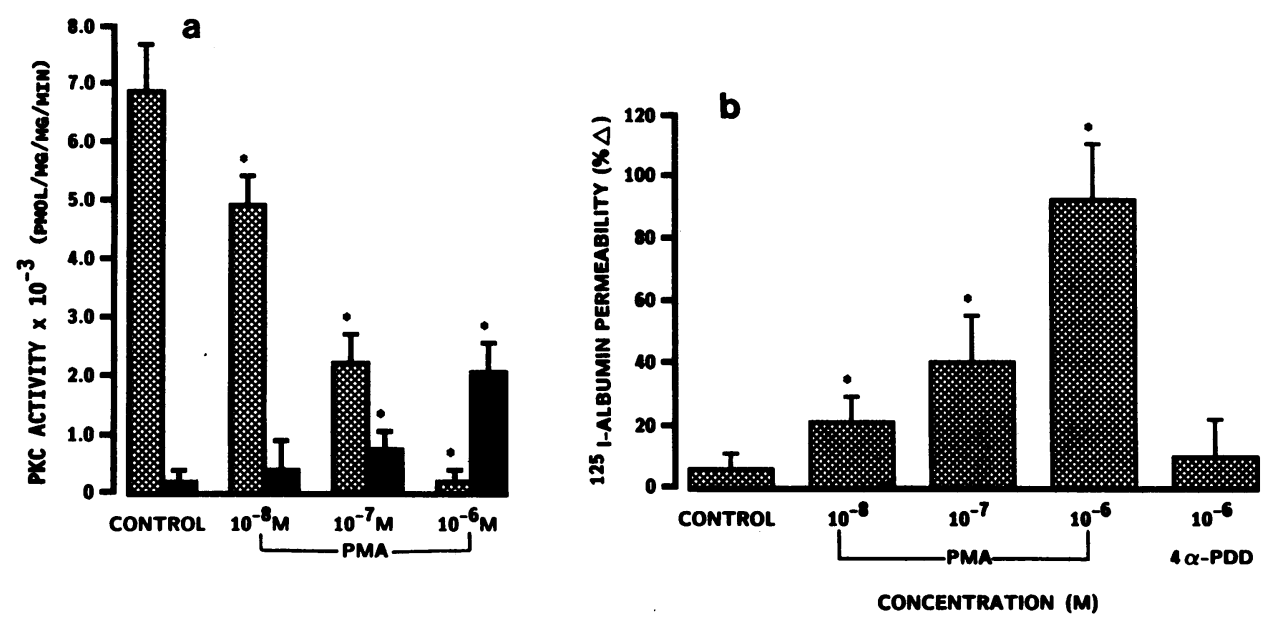

Figure 1. (a) Cytosolic (hatched bars) and membrane (solid bars) activities of PKC from bovine pulmonary artery endothelial cells exposed to PMA. Control intervention was with DMSO vehicle. Values represent the mean $\pm S E M$ of three experiments. PKC activation resulted in the translocation of the PKC. ${ }^{*} P$ $<0.05$ compared to control. (b) Change in ${ }^{125} \mathrm{I}$-albumin clearance rates across bovine pulmonary artery endothelial cell monolayers exposed to PMA or $4 \alpha$-phorbol didecanoate ( $4 \alpha$-PDD). Control intervention was with DMSO vehicle.

Values represent the mean \pm SEM of four experiments. PMA produced a concentration-dependent increase in endothelial albumin permeability. ${ }^{*} P<0.05$ compared to control. plates (Gibco Laboratories). All experiments were made in triplicate, using an LDH Assay Kit (Sigma Chemical Co.) and Beckman DU-50 spectrophotometer to measure LDH release (Beckman Instruments, Inc., Fullerton, $\mathrm{CA}$ ). Specific release was determined at baseline and after $4 \mathrm{~h}$ of exposure to PMA $\left(10^{-6} \mathrm{M}\right)$ and the results were compared to total LDH determined after cell lysis using $1 \%$ Triton X-100 (Fisher Scientific Co., Springfield, NJ).

Statistical analysis. Changes in ${ }^{125} \mathrm{I}$-albumin clearance across BPAE were analyzed using analysis of variance (ANOVA). Significance of the changes (set at $P<0.05$ ) was determined by Student's $t$ test.

\section{Results}

Activation of endothelial PKC and its effect on endothelial monolayer permeability. The activity of PKC in confluent bovine pulmonary artery endothelial cells was studied before and after exposure to increasing concentrations of the lipophilic phorbol ester, PMA (Fig. 1 a). Quiescent monolayers exhibited PKC activity predominantly in the cytosolic fraction, with only negligible activity in the membrane fraction (Fig. $1 a$ ). Exposure of bovine pulmonary artery endothelial cells to PMA for $5 \mathrm{~min}$ resulted in a characteristic concentration-dependent decrease in cytosolic PKC activity and increase in the membrane-associated PKC activity (Fig. 1 a).

Exposure of bovine pulmonary artery endothelial cells to PMA induced concentration-dependent increases in the ${ }^{125} \mathrm{I}$ albumin clearance rates compared with DMSO control (Fig. 1 b). A maximal increase in ${ }^{125} \mathrm{I}$-albumin clearance rate of $92 \pm 18 \%$ above baseline was observed at PMA concentration of $10^{-6} \mathrm{M}$. Increases in ${ }^{125} \mathrm{I}$-albumin clearance rates occurred within $5 \mathrm{~min}$ of exposure, and remained elevated for the 30min duration of the assay. Exposure of bovine pulmonary artery endothelial cells to $10^{-6} \mathrm{M} 4 \alpha$-phorbol didecanoate, a phorbol ester that does not activate PKC (29), did not increase permeability compared to the DMSO vehicle control (Fig. 1 $b$ ). The correlation between the PMA-induced activation of PKC and the increases in permeability mediated by PMA is shown in Fig. 2. The clearance rate of ${ }^{125} \mathrm{I}$-albumin increased with increases in the membrane-associated PKC activity (Fig. 2).
Release of LDH from bovine pulmonary artery endothelial monolayers was determined at baseline and after exposure to $10^{-6} \mathrm{M}$ PMA to assess whether the highest concentration of PMA caused endothelial cell lysis. LDH release was not significantly increased above baseline after exposure to PMA for up to $4 \mathrm{~h}$ (Table I).

Effect of $O A G$ on endothelial permeability. The diacylglycerol PKC activator, OAG $\left(10^{-5}\right.$ and $\left.10^{-4} \mathrm{M}\right)$, increased transendothelial ${ }^{125} \mathrm{I}$-albumin clearance rates compared to baseline values, whereas exposure to MOG, a monoacylglycerol which does not activate PKC, did not increase ${ }^{125} \mathrm{I}$-albumin clearance rates above baseline values (Fig. 3).

Effect of inhibition of PKC activation on endothelial permeability increases. The effects of the isoquinolinylsulfonamide inhibitor $\mathrm{H} 7$ and the control isoquinolinylsulfonamide

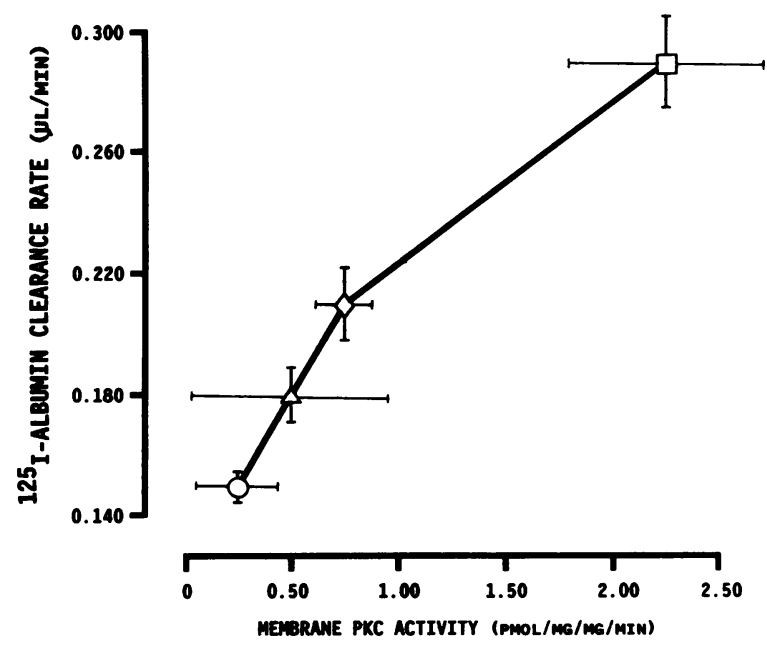

Figure 2. Relationship of membrane PKC activity to the ${ }^{125} \mathrm{I}$-albumin clearance rates across bovine pulmonary artery endothelial cells exposed to $(O)$ vehicle, $(\triangle) 10^{-8} \mathrm{M},(\diamond) 10^{-7} \mathrm{M}$, and $(\square) 10^{-6} \mathrm{M}$ PMA. Control intervention was with DMSO vehicle. Values represent the mean \pm SEM of three experiments (PKC activity) or four experiments ( ${ }^{125} \mathrm{I}$-albumin clearance rates). 
Table I. LDH Release from Bovine Pulmonary Endothelial Monolayers

\begin{tabular}{lrc}
\hline & LDH release & \% Total \\
\hline & $U$ & \\
Baseline & $36 \pm 10$ & 3.3 \\
PMA $\left(10^{-6} \mathrm{M}\right)$ & $20 \pm 15$ & 1.8 \\
Total & $1,069 \pm 33$ & 100 \\
\hline
\end{tabular}

Values represent mean \pm SEM of six experiments.

Total is LDH release after treatment with $1 \%$ Triton X-100.

HA1004 on PKC activity are shown in Fig. $4 a$. In the preparations of purified cytosolic protein extracts, the $\mathrm{H} 7$ concentration of $25 \mu \mathrm{M}$ significantly inhibited the phospholipid-dependent kinase activity, whereas HA1004 was ineffective at the concentration of $25 \mu \mathrm{M}$ (Fig. $4 a$ ). Both compounds were ineffective at $10 \mu \mathrm{M}$ but effective inhibitors at $50 \mu \mathrm{M}$; therefore, we used H7 and HA1004 each at concentration of $25 \mu \mathrm{M}$ for these studies. The effects of preincubating bovine pulmonary artery endothelial monolayers with $25 \mu \mathrm{M} \mathrm{H7}$ are shown in Fig. $4 \mathrm{~b}$. The increase in ${ }^{125} \mathrm{I}$-albumin permeability observed after exposure to $10^{-7} \mathrm{M}$ PMA was significantly reduced, whereas preincubation with $25 \mu \mathrm{M}$ HA1004 did not prevent the increase in permeability mediated by PMA (Fig. $4 b$ ).

Time course of the PMA effect. Fig. 5 a indicates that ${ }^{125} \mathrm{I}-$ albumin permeability increased after PMA challenge, but then returned to baseline within $16 \mathrm{~h}$ of exposure to PMA $\left(10^{-7} \mathrm{M}\right)$. The further addition of PMA $\left(10^{-7} \mathrm{M}\right)$ to monolayers preexposed to PMA $\left(10^{-7} \mathrm{M}\right)$ for 8 or $16 \mathrm{~h}$ did not result in signifcant increases in permeability above the respective control values (Fig. 5 b). A 16-h incubation with PMA $\left(10^{-7} \mathrm{M}\right)$ followed by 5 min incubation with vehicle resulted in a marked decrease in cytosolic PKC activity (Table II). Moreover, PKC activity was not translocated to the membrane fraction after

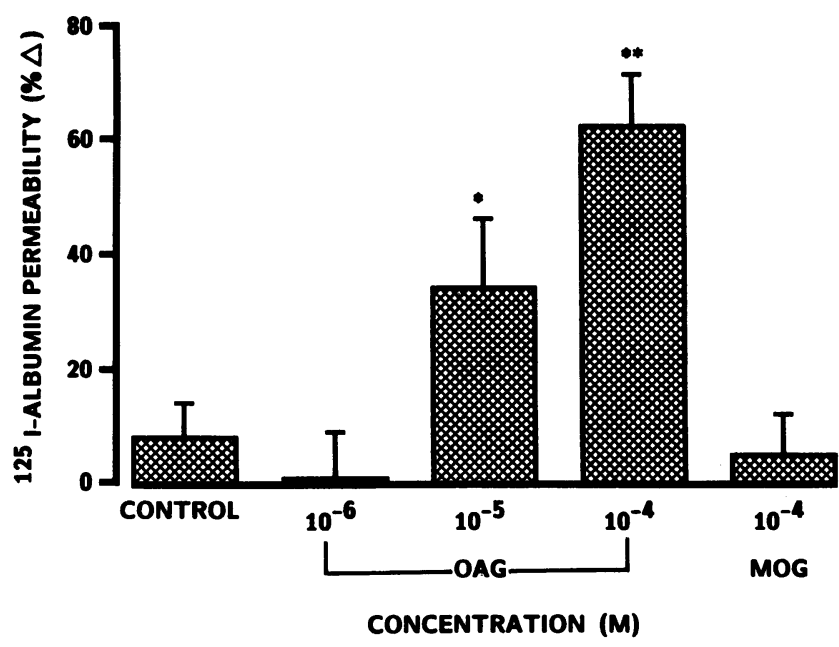

Figure 3. Change in ${ }^{125} \mathrm{I}$-albumin clearance rates across bovine pulmonary artery endothelial cells exposed to OAG or MOG. Control intervention was with HBSS. Values represent the mean \pm SEM of four experiments. The active 1,2-diacylglycerol analogue OAG produced a concentration-dependent increase in endothelial albumin permeability. ${ }^{*} P<0.05$ compared to control; ${ }^{* *} P<0.001$ compared to control.
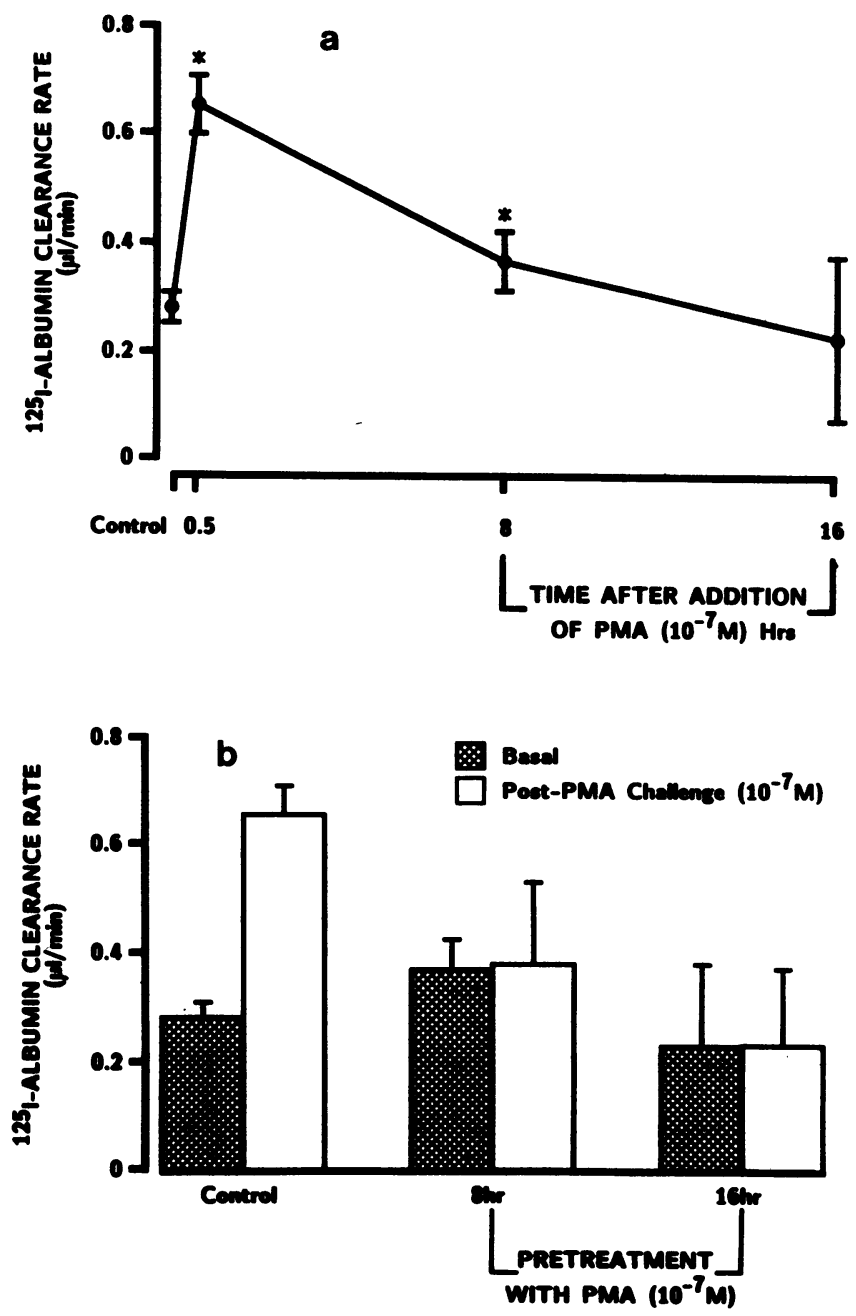

Figure 4. (a) Effects of varying concentrations of $\mathrm{H} 7$ and HA1004 on cytosolic PKC activity in bovine pulmonary artery endothelial cells. Control intervention was with HBSS. Values represent the mean \pm SEM of three experiments. ${ }^{*} P<0.05$ compared to control; ${ }^{* *} P<0.001$ compared to control. $(b){ }^{125} \mathrm{I}$-albumin clearance rates across bovine pulmonary artery endothelial cells preincubated with either H7 or HA1004 (at effective concentrations of $25 \mu \mathrm{M}$ ) before challenge with PMA. Control intervention was with DMSO vehicle. Values represent the mean \pm SEM of three experiments. ${ }^{*} P<0.05$ compared to control; ${ }^{* *} P<0.05$ compared to PMA response.

the prolonged PMA treatment, indicating that PKC was not persistently activated. This is in contrast to PKC activation observed after acute exposure to PMA (Fig. 1 a). A 16-h incubation with PMA $\left(10^{-7} \mathrm{M}\right)$ followed by $5 \mathrm{~min}$ challenge with PMA $\left(10^{-7} \mathrm{M}\right)$ also did not result in translocation of PKC activity to the membrane-bound fraction, further indicating that PKC was depleted following PMA treatment regimen used in the present study.

Effects of phospholipase $C(P L C)$. We investigated whether increased phosphotidylinositide turnover induced by PLC would activate endothelial cell PKC and also increase endothelial monolayer permeability to ${ }^{125} \mathrm{I}$-albumin. Concentrationdependent increases in ${ }^{125} \mathrm{I}$-albumin clearance rates were noted after exposure of the endothelial monolayer to PLC (Fig. $6 a$ ). PLC $(1 \mathrm{U} / \mathrm{ml})$ also activated endothelial cell PKC compared to control (Fig. 6 b). The PLC-mediated increase in permeability 

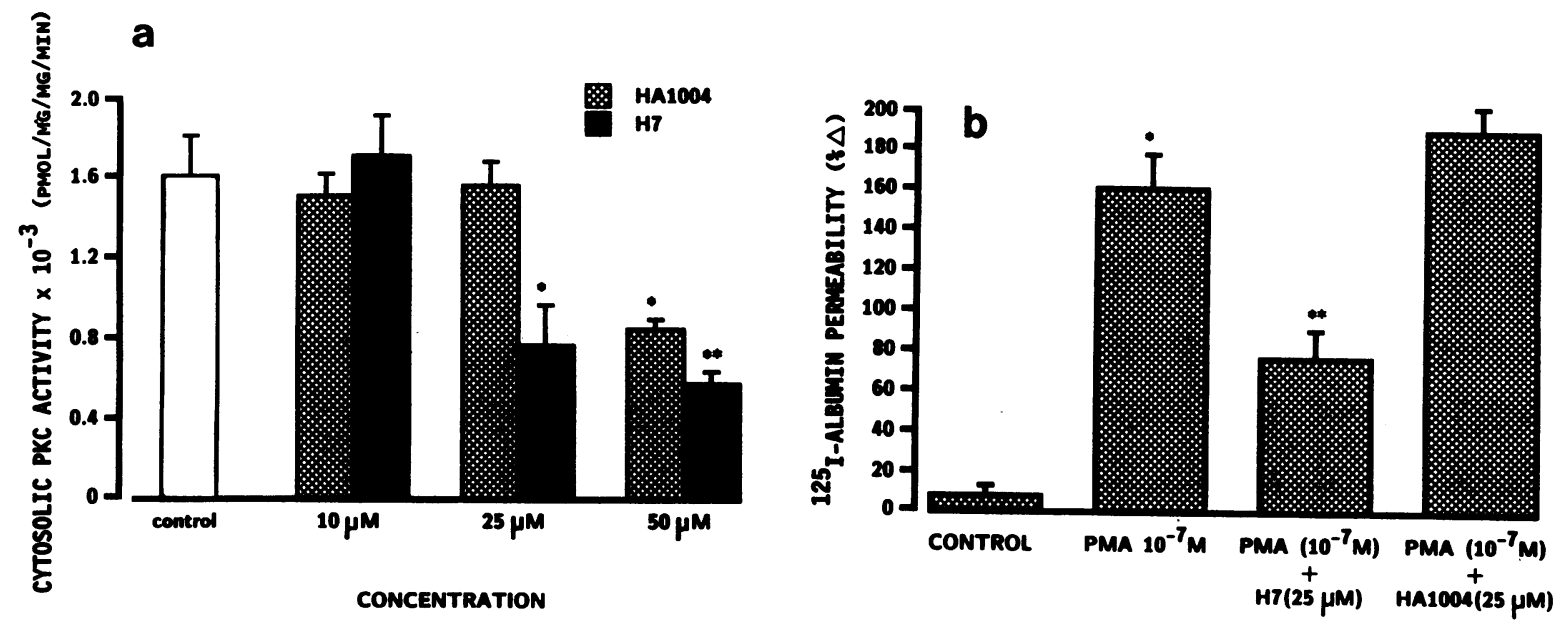

Figure 5. (a) Time course of the effect of PMA $\left(10^{-7} \mathrm{M}\right)$ on transendothelial ${ }^{125} \mathrm{I}$-albumin clearance rate. Control intervention was with DMSO vehicle. Values represent the mean \pm SEM of three experiments. ${ }^{*} P<0.01$ compared to control. $(b)$ Effect of PMA $\left(10^{-7} \mathrm{M}\right){ }^{125} \mathrm{I}$-albumin clearance rate in endothelial monolayers preexposed to PMA $\left(10^{-7} \mathrm{M}\right)$ for 8 or $16 \mathrm{~h}$. The hatched bars indicate the preintervention clearance rates and the clear bars indicate the clearance rates after the second challenge with PMA for 5 min. Control indicates the absence of PMA preexposure. Values represent the mean \pm SEM of three experiments. The second PMA challenge did not significantly increase endothelial albumin permeability. ${ }^{*} P<0.01$ compared to control; ${ }^{* *} P<0.01$ compared to preintervention clearance.

was inhibited by preincubation with $\mathrm{H}-7(25 \mu \mathrm{M})$, but not with HA1004 $(25 \mu \mathrm{M})$ (Fig. $6 c$ ). This concentration range of PLC $(0.1-10 \mathrm{U} / \mathrm{ml})$ did not result in endothelial LDH release, indicating that the permeability increase was not due to cytolysis.

Effects of $\alpha$-thrombin. Addition of $\alpha$-thrombin to bovine pulmonary artery endothelial monolayers resulted in concentration-dependent increases in ${ }^{125} \mathrm{I}$-albumin clearance rates (Fig. 7 a) confirming our previous findings (3). Exposure of the endothelial monolayer to $\alpha$-thrombin also produced concentration-dependent PKC activation (Fig. 7 b). Preincubation of endothelial cells with $\mathrm{H} 7(25 \mu \mathrm{M})$ before the addition of $\alpha$ thrombin $\left(10^{-8} \mathrm{M}\right)$ significantly reduced the $\alpha$-thrombin-mediated increase in endothelial permeability to ${ }^{125} \mathrm{I}$-albumin, whereas HA1004 was not protective (Fig. 7 c).

Table II. Effect of PMA Challenge on Cytosolic and Membranebound PKC Activities of Endothelial Cell Monolayers Preexposed to PMA for $16 \mathrm{~h}$

\begin{tabular}{lccc}
\hline & \multicolumn{3}{c}{ Protein kinase $\mathrm{C}$ activities $(\mathrm{pmol} / \mathrm{mg} / \mathrm{mg} / \mathrm{min}) \times 10^{-3}$} \\
\cline { 2 - 4 } & Control & PMA $/$ Control & PMA/PMA \\
\hline Cytosolic & $18.7 \pm 5.9$ & $1.3 \pm 0.8^{*}$ & $3.2 \pm 1.0^{*}$ \\
Membrane & $3.7 \pm 0.5$ & $3.9 \pm 0.4$ & $3.0 \pm 1.8$
\end{tabular}

Groups were as follows: $16 \mathrm{~h}$ incubation with DMSO vehicle followed by $5 \mathrm{~min}$ incubation with vehicle (Control), $16 \mathrm{~h}$ incubation with PMA $\left(10^{-7} \mathrm{M}\right)$ followed by $5 \mathrm{~min}$ incubation with vehicle (PMA/Control), and $16 \mathrm{~h}$ incubation with PMA $\left(10^{-7} \mathrm{M}\right)$ followed by 5 min incubation with $10^{-7}$ M PMA (PMA/PMA). Values represent the mean \pm SEM of three experiments. There were maximal decreases in the cytosolic and membrane PKC activities after the $16 \mathrm{~h}$ PMA challenge; the second PMA challenge did not produce a decrease in the cytosolic activity or an increase in the membranebound activity.

* Different from control group.

\section{Discussion}

In the present study, we have shown that the activation of endothelial cell PKC by various interventions leads to increases in endothelial permeability to albumin. This conclusion is based on the following observations: $(a)$ PKC activation was correlated with the increases in ${ }^{125} \mathrm{I}$-albumin clearance rates for each intervention used (PMA, phospholipase $C$, and $\alpha$-thrombin), (b) the inactive analogues of the PKC activators (4 $\alpha$-phorbol didecanoate and 1-mono-oleoyl glycerol) neither increased the transendothelial ${ }^{125} \mathrm{I}$-albumin clearance rates nor activated endothelial cell PKC, $(c)$ inhibition of endothelial PKC using $\mathrm{H} 7$ significantly reduced the permeability-increasing effects of the interventions (i.e., PMA, $\alpha$-thrombin, and PLC), whereas the control compound HA1004 had no effect, (d) endothelial permeability by PMA challenge after PKC depletion induced by an initial $16 \mathrm{~h}$ of PMA treatment, and $(e)$ none of the interventions caused endothelial cell lysis at the concentrations used, indicating that the permeability increases were the result of altered endothelial barrier function as opposed to cytolysis. Although we have established an important role for PKC activation in mediating the increase in endothelial permeability to albumin, we cannot rule out the possible involvement of other endothelial cell kinases (e.g., cAMP- and cGMP-dependent kinases), which have not been examined.

PKC is primarily a cytosolic enzyme in quiescent cells (13, 22 ), which was also the case in the resting bovine pulmonary artery endothelial cells used in this study. The enzyme PKC upon activation covalently binds to cell membranes where it exerts its effects (13). Endothelial PKC activation was demonstrated as a characteristic shift in PKC activity from the cytosol to the cell membrane. In the present study, exposure of bovine pulmonary artery endothelial cells to PMA, PLC, or $\alpha$-thrombin resulted in decreases in cytosolic PKC activity and increases in covalently bound membrane-associated PKC activity, consistent with activation of the enzyme.

Increased phosphatidylinositide turnover is an important 

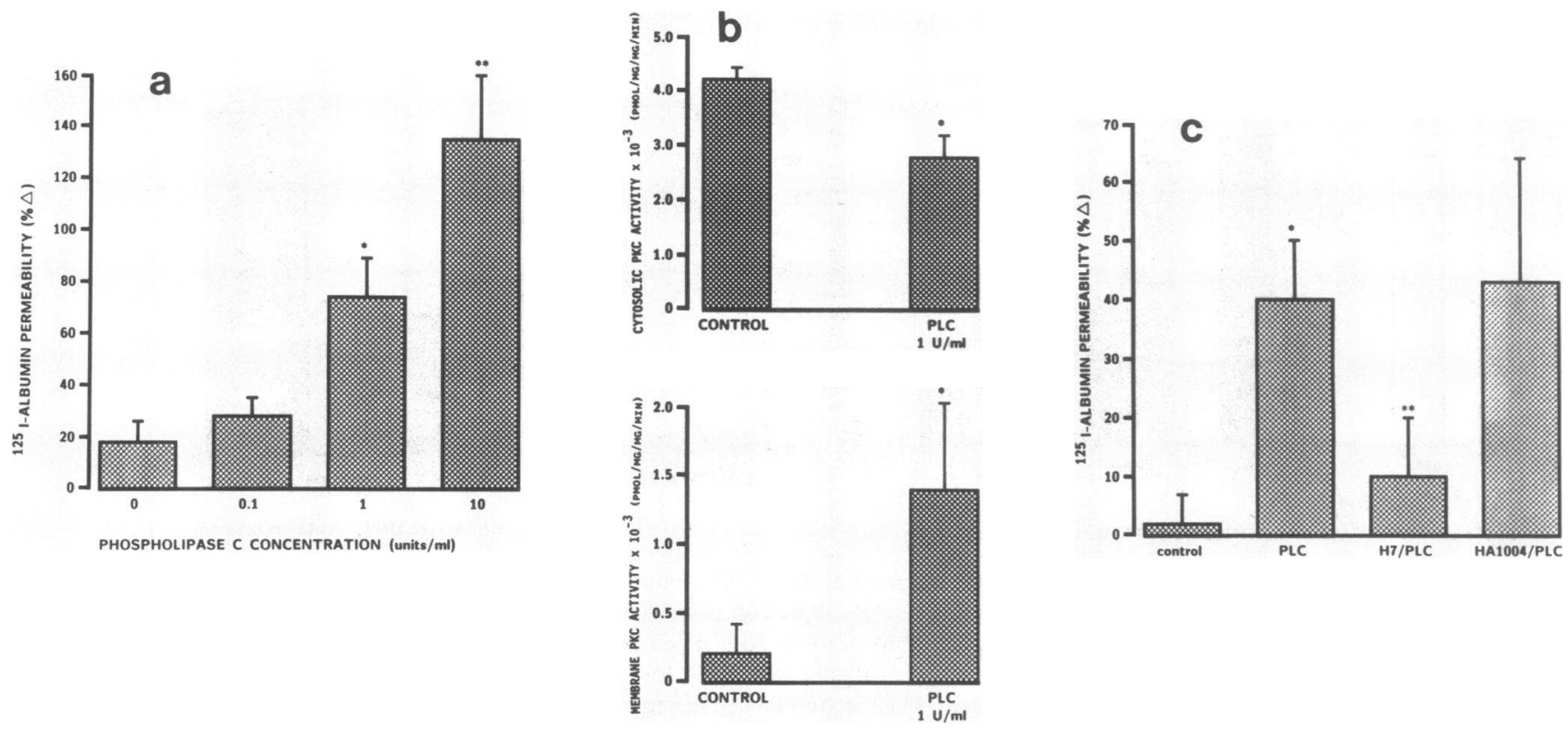

Figure 6. (a) Changes in ${ }^{125} \mathrm{I}$-albumin clearance rates across bovine pulmonary artery endothelial cells exposed to increasing PLC concentrations. Control intervention was with HBSS. Values represent the mean \pm SEM of three experiments. ${ }^{*} P<0.05$ compared to control; ${ }^{*} P<0.001$ compared to control. (b) Cytosolic and membrane activities of PKC from bovine pulmonary artery endothelial cells exposed to PLC. Control intervention was with HBSS. Values represent the mean \pm SEM of three experiments ${ }^{*} P<0.05$ indicates difference from control. (c) Clearance rates of ${ }^{125} \mathrm{I}$-albumin across bovine pulmonary artery endothelial cells preincubated with either $25 \mu \mathrm{M} \mathrm{H} 7$ or $25 \mu \mathrm{M}$ HA 1004 before exposure to PLC $(1 \mathrm{U} / \mathrm{ml})$. Control intervention was with HBSS. Values represent mean \pm SEM of three experiments. ${ }^{*} P<0.05$ compared to control; ${ }^{* *} P$ $<0.05$ compared to PLC response.
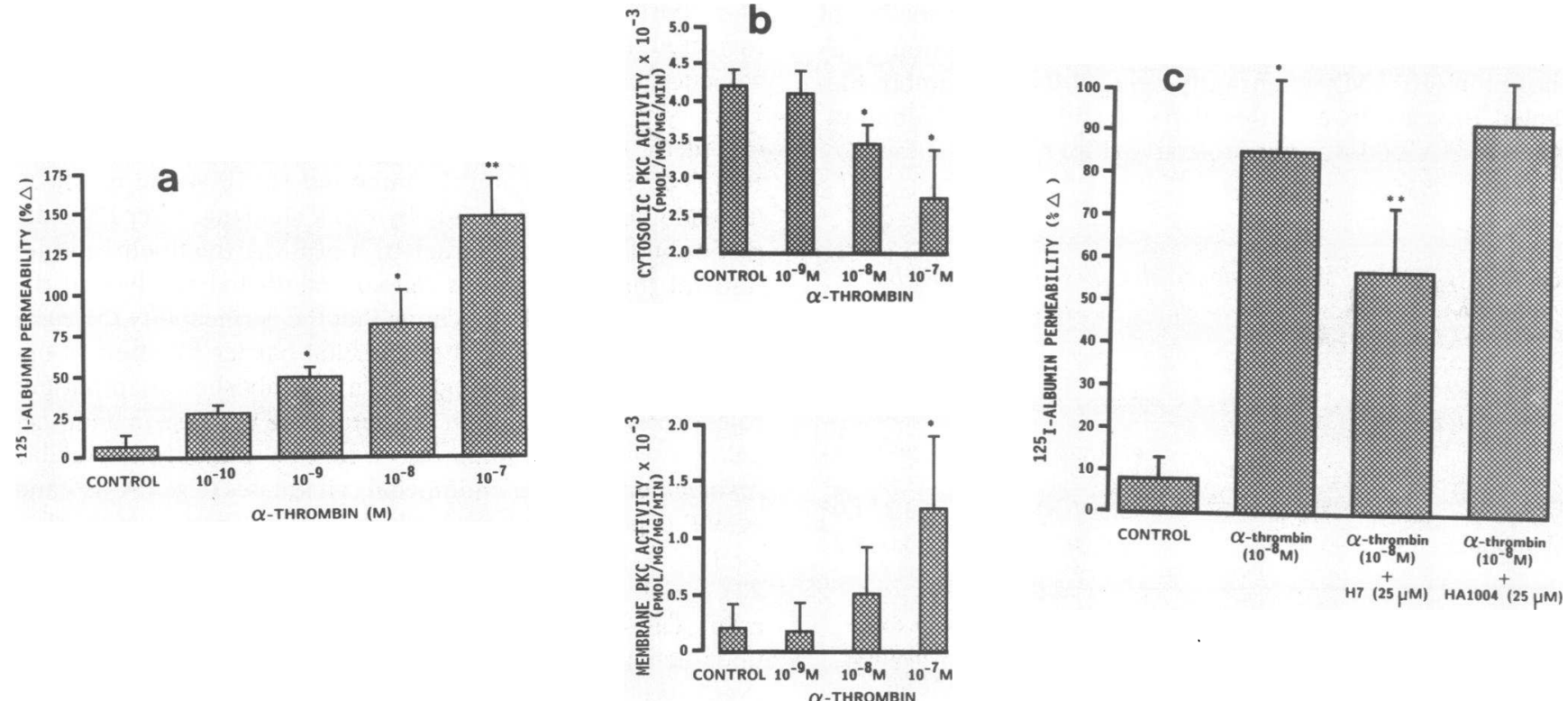

Figure 7. (a) Change in ${ }^{125} \mathrm{I}$-albumin clearance rates across bovine pulmonary artery endothelial cells exposed to increased $\alpha$-thrombin concentrations. Control intervention was with HBSS. Values represent the mean \pm SEM of three experiments. ${ }^{*} P<0.05$ compared to control; ${ }^{* *} P$ $<0.001$ compared to control. (b) Cytosolic and membrane activities of PKC from bovine pulmonary artery endothelial cells exposed to $\alpha$ thrombin. Control intervention was with HBSS. Values represent mean \pm SEM of three experiments. ${ }^{*} P<0.05$ compared to PKC activity of control. (c) Clearance rates of ${ }^{125}$ I-albumin across bovine pulmonary artery endothelial cells preincubated with either $25 \mu \mathrm{M} H 7$ or $25 \mu \mathrm{M}$ HA004 before exposure to $\alpha$-thrombin. Control intervention was with HBSS. Values represent the mean \pm SEM of three experiments. ${ }^{*} P<0.05$ compared to control; ${ }^{* *} P<0.05$ compared to thrombin response. 
signal for PKC activation in many cell types. This process is catalyzed by activation of membrane phospholipase C (31), a phosphodiesterase, which hydrolyzes phosphatidylinositides to (a) diacylglycerols (which directly activate PKC [13]) and (b) inositol phosphates (which mobilizes intracellular calcium $[32,33])$. Our results indicate that PLC increases endothelial permeability and activates PKC; moreover, the permeability increase was partially prevented by PKC inhibition. Therefore, the PLC-induced increase in permeability occurs as a consequence of increased endothelial cell phosphatidylinositide turnover and the resultant PKC activation.

We examined whether $\alpha$-thrombin, a mediator of coagulation and inflammation (26), increases transendothelial permeability by the activation of endothelial PKC. This hypothesis is based on (a) the ability of thrombin to activate PKC in platelets via a GTP-binding protein/phospholipase C-dependent mechanism (34-36), (b) our previous observation that thrombin increases transendothelial albumin permeability (3), and (c) our findings (indicated above) that phospholipase $\mathrm{C}$ and activators of PKC increase transendothelial ${ }^{125} \mathrm{I}$-albumin permeability. Exposure of bovine pulmonary artery endothelial cells to $\alpha$-thrombin resulted in the typical increases in endothelial permeability to ${ }^{125} \mathrm{I}$-albumin (3); but notably, this was associated with the activation of PKC. Both effects were concentration dependent. The thrombin-induced increase in permeability was partially inhibited by $\mathrm{H} 7$, but not by control agent HA1004, indicating that $\alpha$-thrombin-induced activation of PKC is capable of increasing endothelial permeability. However, it is likely that other thrombin-generated signals such as an increase in endothelial cytosolic $\mathrm{Ca}^{2+}(33)$ are also involved, since the thrombin-mediated increase in endothelial permeability was not completely inhibited by $\mathrm{H} 7$.

There may be several possible mechanisms by which PKC activation can increase endothelial permeability. The effect of PKC activation may result from the phosphorylation of cytoskeletal proteins, leading to change in endothelial cell shape (37) and altered cell-cell contact $(15-17,38)$. The cytoskeletal proteins vinculin, vimentin, actin, and myosin light chain are rapidly phosphorylated in response to PKC activation (38-40). The "relaxation" of endothelial cytoskeletal proteins mediated by phosphorylation may result in the transient disruption of interendothelial junctional complexes, and thereby, an increase in endothelial permeability. A similar mechanism may operate in epithelial cells in which PKC activation has been shown to open transiently the intercellular tight junctions $(16,17)$.

In conclusion, we have shown that activation of endothelial cell PKC is an important pathway by which extracellular mediators increase transendothelial albumin transport. Phospholipase C-mediated PKC activation may be a common pathway leading to increased endothelial permeability. Such a common pathway involving PKC activation could explain the similarity in the endothelial permeability responses to a variety of inflammatory mediators.

\section{Acknowledgments}

The authors thank Drs. P. Del Vecchio and Dr. K. Janakedevi for their technical advice and assistance in aspects of this work, and Ms. Lynn McCarthy and Ms. Carol Leahy for expertly typing the manuscript.

Supported by U. S. Public Health Service grants PO1 HL-32418 (Program Project), HL-R01 17016, and T32 HL-07529.

\section{References}

1. Eiseman, B., and D. G. Ashbaugh. 1968. Pulmonary effects of non-thoracic trauma. J. Trauma 8:624-628.

2. Rinaldo, J. E., and R. M. Rogers. 1982. ARDS: Changing concepts of lung injury and repair. N. Engl. J. Med. 306:900-908.

3. Garcia, J. G. N., A. Siflinger-Birnboim, R. Bizios, P. J. Del Vecchio, J. W. Fenton, and A. B. Malik. 1986. Thrombin-induced increases in albumin permeability across the endothelium. J. Cell. Physiol. 128:96-104.

4. Cintora, I., R. L. Goodale, and A. Yamoor. 1972. The effect of endotoxin on the alveolar capillary permeability coefficient in the dog. J. Surg. Res. 13:59-62.

5. Bone, R. C., P. B. Francis, and A. K. Pierce. 1976. Intravascular coagulation associated with the Adult Respiratory Distress Syndrome. Am. J. Med. 61:585-589.

6. Peltier, L. F. 1984. Fat embolism: an appraisal of the problem. Clin. Orthop. 187:3-17.

7. Katsenstein, A. A., C. M. Bloor, and A. A. Liebow. 1976. Diffuse alveolar damage-the role of oxygen, shock and related factors. Am. J. Pathol. 85:210.

8. Gould, V. E., R. Tosco, and R. F. Wheelis. 1972. Oxygen pneumonitis in man: ultrastructural observations on the development of the alveolar lesions. Lab. Invest. 26:499-508.

9. Bachofen, M., and E. R. Weibel. 1982. Structural alterations of lung parenchema in the adult respiratory distress syndrome. Clin. Chest. Med. 3:35-56.

10. Malik, A. B. 1983. Pulmonary microembolism. Physiol. Rev. 63:1114-1207.

11. Galdal, K. S., S. A. Evensen, and E. Nilsen. 1983. Thrombininduced shape change of cultured endothelial cells: metabolism and functional observations. Thromb. Res. 32:57-66.

12. Siess, W., P. C. Weber, and E. G. Lapetina. 1984. Activation of phospholipase $\mathrm{C}$ is dissociated from arachidonate metabolism during platelet shape change induced by thrombin or platelet-activating factor: epinephrine does not induce phospholipase $C$ activation or platelet shape change. J. Biol. Chem. 259:8286-8292.

13. Nishizuka, Y. 1984. The role of protein kinase $C$ in cell surface signal transduction and tumour-promotion. Nature (Lond.). 308:693698.

14. Gainer, M. 1985. Diacylglycerol inhibits gap junction communication in cultured epithelial cells: evidence for a role of protein kinase C. Biochem. Biophys. Res. Comm. 126:1109-1113.

15. Ojakian, G. K. 1981. Tumor promoter-induced changes in the permeability of epithelial cell tight junctions. Cell. 23:95-98.

16. Mullin, J. M., and T. G. O'Brien. 1986. Effects of tumor promoters on LLC-PK1 renal epithelial tight junctions and transepithelial fluxes. Am. J. Physiol. 251:C597-C602.

17. Shasby, D. M., M. Yorek, and S. S. Shasby. 1988. Exogenous oxidants initiate hydrolysis of endothelial cell inositol phospholipids. Blood. 72:491-499.

18. Smith, W. L. 1986. Prostaglandin synthesis and its compartmentation in vascular smooth muscle and endothelial Cells. Annu. Rev. Physiol. 48:251-262.

19. Siflinger-Birnboim, A., J. A. Cooper, P. J. Del Vecchio, H. Lum, and A. B. Malik. 1988. Selectivity of the endothelial monolayer: Effects of increased permeability. Microvasc. Res. 36:216-227.

20. Bocci, V. 1964. Efficient Labeling of serum proteins with ${ }^{131}$ I using chloramine-T. Int. J. Appl. Radiat. 15:449-456.

21. Cooper, J. A., P. J. Del Vecchio, F. L. Minnear, K. E. Burhop, W. M. Selig, J. G. N. Garcia, and A. B. Malik. 1987. Measurement of albumin permeability across endothelial monolayers in vitro. J. Appl. Physiol. 62:1076-1083.

22. Wolfson, M., L. C. McPhail, V. N. Nasrallah, and R. Snyderman. 1985. Phorbol myristate acetate mediates redistribution of protein kinase $C$ in human neutrophils: potential role in the activation of the respiratory burst enzyme. J. Immunol. 135:2057-2062.

23. Sahal, D., and Y. Fujita-Yamaguchi. 1987. Protein kinase C 
assay by paper-trichloroacetic acid method: high performance using phosphocellulose paper and washing an ensemble of samples on flat sheets. Anal. Biochem. 167:23-30.

24. Thomas, T., R. Gopalakrishna, and W. Anderson. 1987. Hormone and tumor promoter activation of protein kinase $\mathrm{C}$ in intact cells. Methods Enzymol. 141:399.

25. Lowry, O. H., N. J. Rosebrough, and A. L. Farr, and R. J. Randall. 1951. Protein measurement with the Folin phenol reagent. $J$. Biol. Chem. 193:265-275.

26. Fenton, J. W., II, M. J. Fasco, A. B. Stackrow, D. L. Aronson, A. M. Young, and J. S. Finlayson. 1977. Human thrombins. Productions evaluation and properties of $\alpha$-thrombin. J. Biol. Chem. 252:3587-3589.

27. Hidaka, H., M. Inagaki, S. Kawamoto, and Y. Sasaki. 1984. Isoquinolinosulfonamides, novel and potent inhibitors of cyclic nucleotide-dependent protein kinase and Protein Kinase C. Biochemistry. 23:5036-41.

28. Wrobleski, F., and J. S. LaDue. 1955. Lactic dehydrogenase in blood. Proc. Soc. Exp. Biol. Med. 90:210-217.

29. Hecker, E. 1971. Isolation and characterization of the cocarcinogenic principles from Croton oil. Methods Cancer Res. 6:439-484.

30. Blackshear, P. J., L. A. Witters, P. R. Girard, J. F. Kuo, and S. N. Quamo. 1985. Growth factor-stimulated protein phosphorylation in 3T3-4 Cells. J. Biol. Chem. 260:13304-13315.

31. Irvine, R. F. 1982. How is the level of free arachidonic acid controlled in mammalian cells? Biochem. J. 204:3-16.
32. Berridge, M. J., and R. F. Irvine. 1984. Inositol triphosphate, a novel second messenger in cellular signal transduction. Nature (Lond.). 312:315-317.

33. Lum, H., P. J. Del Vecchio, A. S. Schneider, M. S. Goligorsky, and A. B. Malik. 1989. Calcium dependence of the thrombin-induced increase in endothelial albumin permeability. J. Appl. Physiol. 66:1471-1476

34. Litosch, I., and J. N. Fain. 1986. Regulation of phosphoinositide breakdown by guanine nucleotides. Life Sci. 39:187-194.

35. Agranoff, B. W., M. Pushpalatha, and E. B. Sequin. 1983. Thrombin-induced phosphodiesteratic cleavage of phosphatidyl bisphosphate in human platelets. J. Biol. Chem. 258:2076-2078.

36. Gilman, A. G. 1987. G proteins: transducers of receptor-generated signals. Annu. Rev. Biochem. 56:615-649.

37. Yamasaki, H., T. Enomoto, N. Martek, Y. Shiba, and Y. Kanno. 1983. Tumour promoter-mediated inhibition of cell-cell communication. Exp. Cell Res. 146:297-308.

38. Werth, D. K., J. E. Niedel, and K. Pastan. 1983. Vinculin, a cytoskeletal substrate of protein kinase C. J. Biol. Chem. 258:1142311426.

39. Huang, C. H., J. F. Devanney, and S. P. Kennedy. 1988. Vimentin, a cytoskeletal substrate of protein kinase C. Biochem. Biophys. Res. Commun. 150:1006-1011.

40. deLanerolle, P., and M. Nishikawa. 1988. Regulation of embryonic smooth muscle myosin by protein kinase C. J. Biol. Chem. 263:9071-9074. 